\title{
STRATEGI DAKWAH PADA MASYARAKAT SAMIN
}

\author{
Luthfi Hidayah \\ Dosen Fakultas Dakwah Jurusan Komunikasi Penyiaran Islam \\ Institut Pesantren Sunan Drajat Paciran Lamongan Jawa Timur \\ Email: fathinamura@gmail.com
}

\begin{abstract}
7 he life of the Samin community has undergone many changes and shifts since they embraced Islam. This paper examines the strategy of implementing da'wah to their community. The implementation of Islamic da'wah has existed among them, which can be seen from Islamic nuances, carried out by Fatayat, Muslimat, TPQ, the Hadrah Art group, and the Selapanan Recitation group. The activity became a forum for the development of Islamic teachings among the community.

This paper concludes that the da'wah strategy used by the Samin community is the strategy of preaching bi al-hikmah, namely preaching by looking at the situation and condition of them first so that they do not feel compelled or objected to accepting and implementing Islamic teachings. This strategy is quite appropriate to be applied, because before delivering da'wah, da'i already knew the situation and conditions of them. Through the da'wah strategy mentioned above, they can receive da'wah well so that it has a positive impact on their lives.
\end{abstract}

Keywords: Islamic Da'wah, Local Wisdom, Samin Society.

\begin{abstract}
ABSTRAK
$\mathrm{K}$ ehidupan masyarakat Samin telah mengalami banyak perubahan dan pergeseran sejak mereka memeluk agama Islam. Makalah ini mengkaji tentang strategi pelaksanaan dakwah pada kehidupan mereka. Pelaksanaan dakwah Islam telah ada di kalangan komunitas ini, yang terlihat dari adanya kegiatan yang bernuansa keislaman, yang dilakukan oleh Fatayat, Muslimat, TPQ, kelompok Seni Hadrah, dan kelompok Pengajian Selapanan. Kegiatan tersebut menjadi wadah bagi pengembangan ajaran Islam di kalangan masyarakat Samin.

Makalah ini menyimpulkan bahwa strategi dakwah yang digunakan di kalangan masyarakat Samin adalah strategi dakwah bi al-hikmah, yaitu berdakwah dengan melihat situasi dan kondisi mereka terlebih dahulu sehingga mereka tidak merasa terpaksa atau keberatan dalam menerima dan menjalankan ajaran-ajaran Islam. Strategi ini cukup tepat diaplikasikan karena sebelum menyampaikan dakwah, da' $i$ telah mengetahui situasi dan kondisi mereka. Melalui strategi dakwah tersebut di atas, mereka dapat menerima dakwah dengan baik sehingga memberikan dampak yang positive bagi kehidupan mereka.
\end{abstract}

\section{Kata Kunci: Dakwah Islam, Kearifan Lokal, Masyarakat Samin.}




\section{PENDAHULUAN}

Dalam konteks kemanusiaan, masyarakat dibentuk dan membentuk dengan sendirinya dengan tujuan untuk saling menguatkan, saling toleransi, saling tolong menolong, dan saling melengkapi antara satu dengan yang lainnya. Pada hahikatnya masyarakat me-mpunyai kebiasaan, tradisi, sikap, dan perasaan persatuan yang diikat oleh kesamaan agama, adat istiadat serta kepercayaan yang mereka anut dan dipegang teguh sebagai pedoman dalam kehidupan sehari-hari (Machendrawaty dan Safei, 2001: 5).

Kebudayaan masyarakat berkembang bahkan berubah seiring perjalanan waktu. Hal ini juga terjadi dalam kehidupan masyarakat Samin. Dahulu kala mereka mengikuti kepercayaan Adam dan bahkan hingga saat ini masih ada di antara mereka yang memegang teguh ajaran nenek moyang. Namun, seiring dengan perkembangan zaman sebagian besar masyarakat Samin sudah memeluk agama Islam.

Islam sebagai agama samawi berfungsi sebagai petunjuk jalan bagi umat manusia. Ia melepaskan mereka dari berbagai macam sistem yang gelap dan mengantar mereka menuju sistem kehidupan yang terang. Di lain pihak kehidupan masyarakat berkembang dipengaruhi oleh realitas lingkungannya baik bio-fisik, sosio-kultur maupun psikisnya. Kondisi inilah yang mendorong mereka untuk berbeda pandangan dalam melihat berbagai masalah.

Islam, sesuai dengan fungsinya, harus tetap berada di tengah-tengah kehidupan masyarakat dalam setiap perkembangannya itu. Ia memberikan dasar-dasar wawasan bagi masyarakat mengenai masalah- masalah yang prinsipil, baik aqidah maupun syariah (Hasan, 2005: ix). Untuk menghadapi persoalan-persoalan yang semakin berat dan meningkat, perlu adanya strategi dalam menyebarluaskan Islam kepada seluruh lapisan masyarakat, yakni melalui dakwah.

Dakwah merupakan bagian integral dari ajaran Islam yang wajib dilaksanakan oleh setiap muslim. Kewajiban ini tercermin dari konsep amar maruf dan nahi munkar, yakni perintah untuk mengajak masyarakat melakukan perilaku positifkonstruktif sekaligus mengajak mereka untuk meninggalkan dan menjauhkan diri dari perilaku negatif-destruktif. Konsep ini juga mengandung prinsip perjuangan menegakkan kebenaran Islam dalam dunia sosial guna menyelamatkan masyarakat dan lingkungan-nya dari kerusakan. Karena itu, dakwah memiliki pengertian luas yang tidak hanya berarti mengajak dan menyeru umat manusia agar memeluk Islam. Lebih dari itu, dakwah juga berarti upaya pembinaan masyarakat Islam agar menjadi masyarakat yang lebih berkualitas (khayr ummah) yang dibina dengan ruh tauhid dan ketinggian nilai-nilai Islam.

Perubahan masyarakat yang begitu dinamis seiring dengan laju perkembangan pengetahuan dan teknologi yang pesat merupakan suatu kenyataan yang tidak bisa dihindari. Karena itu, setiap juru dakwah hendaknya melengkapi diri dengan penguasaan ilmu pengetahuan dan teknologi sebelum ia terjun berdakwah di tengah-tengah masyarakat yang majemuk. Mencermati kenyataan ini, maka dalam berdakwah dibutuhkan rumusan srategi dakwah yang tepat sesuai dengan kondisi masyarakat yang dihadapi para juru dakwah (Pimay, 2005: 1-5).

\section{Islamic Communication Journal




\section{Luthfi Hidayah}

Berdasarkan pertimbangan dan alasan yang telah diuraikan di atas dan dikuatkan pula dengan realitas, bahwa masih sedikit perhatian orang, terutama para pelaku dakwah sendiri terhadap pentingnya strategi dalam pelaksanaan dakwah, maka penulis mencoba memberikan kontribusi akademik melalui kajian mengenai strategi dakwah masyarakat pada Samin.

\section{PEMBAHASAN}

\section{Memaknai Dakwah}

Ditinjau dari segi bahasa "da'wah" berarti panggilan, seruan, atau ajakan. Bentuk perkataan ini dalam bahasa Arab disebut mashdar. Sedangkan bentuk kata kerja (fiil)nya adalah da'a-yad'u yang berarti menyeru atau mengajak. Orang yang berdakwah disebut $d a ' i$, dan orang yang menerima dakwah disebut mad'u (Munir dan Ilahi, 2006: 2).

Dalam pengertian istilah, dakwah diartikan dengan beragam pengertian. Faizah dan Lalu Muchsin Effendi menyatakan, bahwa dakwah adalah suatu kegiatan untuk menyampaikan dan mengajarkan serta mempraktikkan ajaran Islam di dalam kehidupan sehari-hari (2009: 19). Sementara itu, menurut Moh. Ali Aziz, secara singkat dakwah merupakan kegiatan peningkatan iman menurut syariat Islam (Aziz, 2009: 19). Pengertian dakwah yang cukup komprehensif disampaikan oleh Samsul Munir Amin, yang menyatakan bahwa dakwah sebagai suatu aktivitas yang dilakukan secara sadar dalam rangka menyampaikan pesan-pesan agama Islam kepada orang lain agar mereka menerima ajaran Islam dan menjalankannya dengan baik dalam kehidupan individual maupun bermasyarakat untuk mencapai kebahagiaan manusia, baik di dunia maupun di akhirat, dengan menggunakan media dan cara-cara tertentu (Munir, 2009: $5)$.

Dari beberapa definisi dakwah di atas, penulis melihat bahwa dakwah merupakan suatu kegiatan menyampaikan agama Islam kepada manusia secara intensif dalam tingkatan peristiwa kehidupan sehingga terwujudlah ajaran Islam dalam kenyataan hidup fardiyah, usrah, jamaah, dan ummah. Oleh karenanya, dakwah tidak hanya dilakukan dalam bentuk kata-kata verbal, tapi juga dalam bentuk tindakan (bi al-hal).

\section{Bagaimana Dakwah Dilakukan?:}

\section{Strategi dan Pendekatan}

Strategi merupakan istilah yang sering diidentikkan dengan "taktik" yang secara bahasa dapat diartikan sebagai "corcerning the movement organisms in respons to external stimulus." Sementara itu, secara konseptual strategi dapat dipahami sebagai suatu garis besar haluan dalam bertindak untuk mencapai sasaran yang telah ditentukan. Strategi juga bisa dipahami sebagai segala cara dan daya upaya untuk menghadapi sasaran tertentu dalam kondisi tertentu agar memperoleh hasil yang diharapkan secara maksimal (Pimay, 2005: 50). Tegasnya, strategi dakwah adalah perencanaan yang berisi rangkaian kegiatan yang didesain untuk mencapai tujuan dakwah tertentu.

Terdapat dua hal yang perlu diperhatikan berkaitan dengan strategi dakwah, yaitu:

Strategi merupakan rencana
tindakan (rangkaian kegiatan
dakwah) termasuk penggunaan
metode dan pemanfaatan berbagai


sumber daya atau kekuatan. Dengan demikian, strategi merupakan proses penyusunan rencana kerja, belum sampai pada tindakan.

2. Strategi disusun untuk mencapai tujuan tertentu. Artinya, arah dari semua keputusan penyusunan strategi adalah pencapaian tujuan. Oleh sebab itu, sebelum menentukan strategi perlu dirumuskan tujuan yang jelas serta dapat diukur keberhasilannya (Aziz, 2009: 349).

Setelah mengetahui penjelasan di atas, penulis dapat menyimpulkan bahwa strategi dakwah merupakan proses menentukan cara dan upaya untuk menghadapi sasaran dakwah dalam situasi dan kondisi tertentu guna mencapai tujuan dakwah secara optimal. Dengan kata lain strategi dakwah adalah siasat, taktik atau maneuver yang ditempuh dalam rangka mencapai tujuan dakwah.

Dengan pengertian di atas, maka pendekatan dakwah dapat dikatakan sebagai bagian dari strategi. Mengenai pendakatan dakwah, al-Qur'an pada Surat al-Nahl: 125 menyatakan:

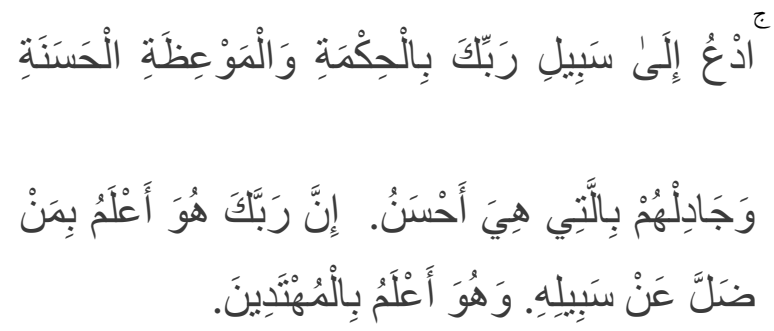

"Serulah (manusia) kepada jalan Tuhan-mu dengan hikmah dan pelajaran yang baik dan bantahlah mereka dengan cara yang baik. Sesungguhnya Tuhanmu Dialah yang lebih mengetahui tentang siapa yang tersesat dari jalan-Nya dan Dialah yang lebih mengetahui orang-orang yang mendapat petunjuk."

Ayat ini menginformasikan, pertama berdakwah hukumnya fardhu ain. Kewajiban berdakwah merupakan tanggung jawab dan tugas setiap muslim kapan dan di mana pun ia berada. Tugas dakwah ini bukan hanya kewajiban para ulama, melainkan juga menjadi kewajiban bagi setiap muslim dan muslimat. Kedua dan yang terpenting, ayat di atas juga menunjukkan bahwa penyiaran agama harus dilakukan dengan sebaik-baiknya sehingga pesan dakwah dapat diterima oleh madu dengan kemauan dan kesadaran hatinya tanpa paksaan.

Oleh karenanya, dalam proses dakwah dibutuhkan pendekatan dakwah yang tepat. Pendekatan dakwah adalah sudut pandang yang digunakan dalam kegiatan/proses dakwah. Terdapat paling tidak tiga pendekatan dakwah, yaitu pendekatan budaya, pendekatan pendidikan, dan pendekatan psikologis. Pendekatanpendekatan ini melihat lebih banyak berfokus pada kondisi mitra dakwah.

Pendekatan yang terfokus pada mitra dakwah lainnya adalah dengan menggunakan bidang-bidang kehidupan sosial kemasyarakatan. Pendekatan dakwah model ini meliputi: pendekatan sosialpolitik, pendekatan sosial-budaya, pendekatan sosial-ekonomi, dan pendekatan sosial-psikologis. Semua pendekatan di atas dapat disederhanakan dengan dua pendekatan, yaitu pendekatan dakwah struktural dan pendekatan dakwah kultural (Aziz, 2009: 347).

Melalui aktivitas dakwah yang dilakukan oleh para penjuru dakwah, sedikit demi sedikit agama Islam mampu menyebar ke berbagai penjuru dunia. Dakwah dapat menyentuh seluruh elemen 


\section{Luthfi Hidayah}

masyarakat, baik yang ada di kota maupun di desa, bahkan di pelosok-pelosok pedesaan terpencil dan terisolir dari kehidupan dunia modern. Karenanya, dapat dikatakan keberadaan dakwah di dalam agama Islam sangat penting dalam menentukan masa depan Islam. Islam tidak akan berkembang dengan baik tanpa adanya aktivitas dakwah.

\section{Objek Studi: Masyarakat Samin,}

\section{Ajaran, dan Tradisi Keagamaannya}

Selain istilah Samin, terdapat istilah Shaminisme yang berasal dari bahasa Siberia, yakni suatu keyakinan terhadap keyakinan dukun, tukang sihir, atau ahli lain yang mampu menggunakan kekuatan gaib untuk mencapai tujuan manusia. Kata Samin diplesetkan masyarakat umum dengan istilah "nyamen," yang diidentikkan sebabagai perbuatan menyalahi tradisi. Menurut masyarakat Samin, kata "Samin" memiliki pengertian "sama," yaitu bersama-sama dengan anak cucu untuk melawan Belanda dan membela bangsa Indonesia sehingga memperoleh kesejahteraan (Kardi, 1996: 8).

Istilah Samin digeser oleh pengikutnya dengan nama Sedulur Sikep, yang berasumsi menghilangkan tendensi negative, yang dilatarbelakangi oleh dua pandangan historis, yaitu pertama, dipimpin seorang petani bernama Ki Samin Surosentiko (Raden Kohar), pujangga Jawa pesisiran pasca-Ronggowarsito yang menyamar sebagai petani untuk menghimpun kekuatan melawan Belanda. Kedua, sebuah julukan yang diberikan aparat desa di Blora bagian selatan dan wilayah Bojonegoro, karena tindakan Samin menentang aparat desa di Blora bagian selatan dan wilayah Bojonegoro dengan cara tidak mau membayar pajak dan memisahkan diri dengan masyarakat umum. Berdasarkan penolakan itulah muncul kata nyamin (Rosyid, 2010: 80). Hal ini diperkuat oleh Mbah Lasiyo sesepuh Samin di Klopoduwur Blora, yang melihat bahwa Samin adalah komunitas Samin yang berjuang untuk melawan Belanda dengan cara tidak mau membayar pajak dan tidak mau mentaati aturan Belanda.

Akibat perlawanan warga Samin terhadap Belanda, Ki Samin disiksa Belanda dengan di tumbuk (dideplok) dilesung. Terdapat beberapa versi wafatnya Ki Samin, yaitu (1) dibuang Belanda di Digul, Irian Jayadan selanjutnya diasingkan di Sawahlunto, Padang Sumatra Barat. Hal ini terjadi karena pada 1890 Ki Samin mengembangkan ajaran Samin di Desa Klopoduwur, Blora. Tahun 1905 setelah banyaknya pengikut, ia pun melawan Belanda; (2) Tahun 1907 Ki Samin diculik Belanda dan dibawa ke Rembang beserta delapan pengikutnya, selanjutnya dibuang di Sawahlunto, Padang, Sumatera Barat, dan wafat tahun 1914 (sebagai tawanan). Pada tahun 1914 Kitab Serat Jamus Kalimosodo disita penguasa, demikian juga kitab Pandoman Kehidupan. Orang-orang Samin tidak lepas dari penyitaan atau perampasan polisi.

Sebelum Ki Samin wafat, ia berpesan pada Ki Engkrek dan Brawok, agar mempertahankan kepercayaan yang diyakininya yakni kepercayaan Adam. Kepercayaan Adam adalah agama perilaku titen, suatu perilaku yang ora srei (tidak membenci siapa pun), ngeru biru (tidak mengganggu sesama) (wawancara, Mbah Lasiyo, 13 Oktober 2014 ). Eksistensi ajaran Samin hingga menjadi komunitas Samin disebarluaskan oleh tokoh (botoh) 
Strategi Dakwah Pada...hal 92-101

Samin. Botoh ini mendatangi setiap daerah yang dikunjungi dengan stategi paseduluran, yakni memperkenalkan dan mengkokohkan talian persaudaraan. Jika mendapatkan respon positif, maka terjadi kesinambungan interaksi. Dalam kegiatan ber-anjangsana antar daerah dilakukan dengan jalan kaki oleh para Leluhur Samin, karena belum adanya sarana-prasarana transportasi.

Apabila ada acara adat maupun perkumpulan sedulur sikep, mereka menggunakan baju tokong (celana yang panjangnya di bawah lutut dan di atas mata kaki), celana tokong (penjang lengannya di bawah sikut, tidak sampai pada pergelangan tangan) berwarna hitam, dan udeng-udeng yang diikatkan di atas kepala (Wawancara, Lasiyo, 08-Maret-2014). Pakaian itu dipakai ketika acara pada bulan Sura. Menurut Mbah Lasiyo (botoh Samin di Dusun Karangpace, Desa Klopoduwur, Kab. Blora):

"Setiap hari Selasa Kliwon tepatnya di bulan Sura, dilaksanakan puasa ngrowot, yaitu selama 7 hari dengan hanya memakan woh-wohan, seperti jambu, gembili, telo, dan tidak memakan garam. Puasa ini bertujuan untuk menebus perilaku orang tua perempuan. Kemudian melakukan deder (seharian tidak duduk), yang dilaksanakan pada malam Jumat. Semua ini dilakukan bertujuan untuk menebus perilaku orang tua laki-laki selama hidup di dunia. Adapun adat istiadat yang wajib ada dalam acara di bulan Sura adalah bancaan berupa bubur abang, putih, abang putih, ketan ireng, jenang klomot (ketan putih diberi santan) dan jenang arang-arang kambang. Ini dilakukan tepatnya pada hari Selasa kliwon" (Wawancara, 13 Oktober 2014).

Ajaran Samin merupakan prinsip yang dijadikan keyakinan hidup warga Samin berupa dasar ajaran (perintah) dalam bentuk etika, pantangan dasar dalam berinteraksi, berdoa dalam beraktivitas, dan menolak aktivitas yang identik dengan action penjajahan Belanda (Rosyid, 2012: 82-84).

\section{Analisis: Strategi Dakwah Bi al-Hikmah Kultural pada Masyarakat Samin}

Sebelum membahas mengenai strategi dakwah pada masyarakat Samin, kita harus mengetahui terlebih dahulu peta kondisi dan situasi problem kehidupan masyarakat tersebut. Di antara problem yang dihadapi masyarakat Samin adalah:

1) Problem aqidah

2) Problem pendidikan

3) Ahkam

4) Akhlaq.

Dalam upaya memberikan dakwah dalam konteks problem di atas diperlukan strategi dakwah yang tepat. Menurut hemat penulis, terkait problem di atas strategi yang dapat dilakukan adalah dengan menerapkan metode dakwah bi al-hikmah. Cara kerjanya adalah dengan melihat situasi dan kondisi masyarakat Samin 


\section{Luthfi Hidayah}

terlebih dahulu, kemudian memberikan materi yang menjadi dasar agama Islam dengan catatan masyarakat Samin tidak merasa terpaksa dan tertekan untuk menerima dakwah.

Sebagai bentuk aktualisasi dari metode al-hikmah, maka jenis dakwah yang dapat digunakan dalam mendakwahi masyarakat Samin adalah dakwah bi al-haal. Karena lebih merupakan aksi dan tindakan nyata, dakwah bi al-haal lebih berorientasi pada pengembangan masyarakat. Dakwah bi alhikmah yang mengambil bentuk dakwah bi lisan al-haal ini adalah ciri dari dakwah kultural.

\section{Dakwah Bi al-Hikmah-Kultural dalam}

\section{Aspek Aqidah}

Aqidah Islam disebut tauhid dan merupakan inti dari kepercayaan. Keyakinan Islam telah masuk dalam kehidupan masyarakat Samin, tetapi pada realitas yang ada, kebanyakan di antara mereka belum pernah atau bahkan tidak pernah melaksanakan apa yang menjadi kewajiban seorang muslim, bahkan hingga saat ini sebagian di antara mereka masih memegang teguh ajaran nenek moyang serta masih melestarikan adat istiadat dalam kehidupan sehari-hari. Dalam mendakwahkan perkara aqidah ini, para da'i dapat mencari titik temu antara keyakinan ajaran Samin yang bersumber dari keyakinan Adam dengan keyakinan Islam, tawhid yang dibawa Nabi Muhammad SAW. Para $d a^{\prime} i$ dapat menampilkan aksi-aksi tawhid yang dibungkus atau ditampilkan melalui ekspresi kebudayaan.

\section{Dakwah Bi al-Hikmah-Kultural dalam}

\section{Aspek Pendidikan}

Pengembangan pendidikan merupakan bagian penting dari upaya mencerdaskan kehidupan anak bangsa, khususnya masyarakat Samin agar menjadi masyarakat maju, mandiri, terbuka, dan berorientasi pada masa depan. Pengembangan pendidikan mesti mampu meningkatkan penguasaan dan pemanfaatan ilmu pengetahuan dan teknologi. Pendidikan diharapkan mampu menghasilkan Sumber Daya Manusia yang berkualitas pada masyarakat Samin sehingga mereka dapat mengikuti perkembangan zaman modern dan tidak ketinggalan dengan masyarakat lainnya.

Dahulu kala masyarakat Samin tidak mementingkan sekolah, bahkan anak-anak mereka tidak diperbolehkan untuk bersekolah sehingga menjadikan mereka tidak berilmu pengertahuan. Akan tetapi seiring dengan perkembangan zaman, masyarakat Samin mengalami perubahan. Anak-anak Samin sudah cukup banyak yang sekolah formal dan rutin mengikuti ngaji TPQ, baik di sore hari maupun di malam hari sehingga sedikit demi sedikit mereka memiliki ilmu pengetahuan, baik agama maupun umum. Problemnya adalah pendidikan yang mereka ikuti (baik pendidikan agama maupun umum) tampaknya belum secara total mampu mengubah diri mereka menjadi lebih terbuka dengan dunia luar dan hal-hal baru.

Dalam konteks ini, dakwah sangat diperlukan. Dakwah tidak cukup dilakukan dengan hanya mengajak mereka untuk bersekolah atau berpendidikan. Dakwah yang lebih tepat adalah dakwah bi alhikmah melalui tindakan nyata (al-hal) dengan cara mendampingi mereka secara 
langsung dalam mengenal pendidikan dan ilmu pengetahuan. Dakwah dalam bentuk kolektif antara Negara dan organisasi sipil Islam seperti NU dan Muhammadiyah dalam membangun rumah sekolah, mendistribusikan para pendidik, membentuk kurikulum yang berbasis local wisdom, serta mendampingi kegiatan kependidikannya sampai pada level evaluasi hasil secara totalitas adalah sebuah strategi dakwah dapat dilakukan dalam konteks ini.

\section{Dakwah Bi al-Hikmah-Kultural dalam}

\section{Aspek Hukum}

Bidang ahkam meliputi soal ibadah, alahwal as-syahsiyah, dan muamalat yang wajib diamalkan oleh setiap muslim. Hal ini diharapkan agar masyakat Samin senantiasa mentaati semua peraturan atau hukum Allah guna mengatur hubungan antara manusia dengan Tuhannya, dan mengatur pergaulan hidup antar sesama manusia dan alam sekitar. Ketika melihat masyarakat Samin, penulis menemukan kejanggalan mengenai kurangnya pemahaman mengenai hukum. Salah satunya seperti ada acara pernikahan, tanpa adanya penghulu pernikahan sudah sah. Karenanya, dakwah bi al-hikmah (al-hal) yang dapat dilakukan adalah dengan mengadopsi dan mengubah-sesuaikan beberapa aspek hukum yang terdapat dalam tradisi Samin dengan hukum-hukum Islam. Hal ini didasarkan pada tradisi dakwah Nabi SAW, bahwa kebiasaan yang berlaku pada masyarakat Arab tidak semerta-merta ditolak, tetapi dicari kesesuaiannya dengan hukum Islam.
Dakwah Bi al-Hikmah-Kultural dalam

\section{Aspek Kebudayaan}

Kebudayaan dan adat istiadat masyarakat Samin masih sangat kental sekali bahkan masih dipercayai dan dilestarikan dalam kehidupan sehari-hari. Apabila kita melihat kondisi masyarakat Samin, tampak bahwa mereka memiliki bermacam-macam adat istiadat yang hingga saat ini masih dipegang teguh. Hal yang dapat dilakukan oleh para juru dakwah adalah memperkuat kesadaran berbudaya. Membungkus dakwah dengan local values dalam melestarikan kebudayaan secara baik, dan tidak keluar dari norma-norma ajaran Islam adalah hal yang dapat dilakukan oleh para $d a$ ' $i$ pada masyarakat Samin. Hal ini dilakukan agar kebudayaan masyarakat Samin dapat berkembang sesuai dengan semangat nilai-nilai Islam.

\section{Dakwah bi al-Hikmah-Kultural dalam}

\section{Aspek Akhlaq}

Rasulullah SAW bersabda: "Aku (muhammad) diutus oleh Allah di dunia ini hanyalah untuk menyempurnakan Akhlak" (Hadist Shahih) (Syukir, 1983: 62). Dalam Islam, akhlak mencakup akhlak mahmudah dan akhlak madzmumah. Melihat kondisi masyarakat Samin yang senantiasa mengedepankan budi pekerti yang baik dan kejujuran, agar nantinya tidak terjadi kesalahan-kesalahan yang keluar dari norma ajaran agama Islam, diperlukan adanya pembelajaran dan pemahaman mendalam mengenai akhlak yang sesuai dengan agama Islam. Dakwah yang dapat dilakukan dalam konteks ini adalah dengan mengadopsi dan mengubah-sesuaikan nilainilai etika yang berlaku dalam masyarakat Samin. Tepatnya, dakwah Islam mesti 


\section{Luthfi Hidayah}

diposisikan sebagai penyempurna bagi nilai-nilai etika yang dijalankan masyarakat Samin.

\section{KESIMPULAN}

Dakwah merupakan suatu kegiatan dalam menyampaikan agama Islam kepada manusia secara intensif dalam tingkatan peristiwa kehidupan sehingga mewujudkan ajaran Islam ke dalam kenyataan hidup fardiyah, usrah, jamaah, dan ummah sehingga terbentuk komunitas dan masyarakat muslim serta peradabannya. Tanpa adanya aktivitas dakwah, masyarakat muslim tidak mungkin terbentuk. Oleh sebab itu, dakwah Islam merupakan faktor penentu yang dapat membentuk masyarakat khair ummah dan baldatun thayyibah wa rabbun ghafur.

Usaha dakwah Islamiyyah yang mencakup segi-segi yang sangat luas dapat berlangsung dengan efektif dan efisien apabila sebelumnya sudah dilakukan dengan tindakan-tindakan persiapan, perencanaan, dan strategi yang matang. Artinya sebelum berdakwah dakwah Islamiyyah harus terprogam secara baik dan dikerjakan sesuai rencana yang sudah disusun, tidak dengan apa adanya.

Apabila kita meninjau kehidupan masyarakat Samin yang masih sangat kokoh dalam memegang teguh adat istiadat dan ajaran nenek moyang, maka sebelum berdakwah, para juru dakwah harus menyusun strategi yang matang untuk menyebarkan agama Islam, agar dapat diterima masyarakat Samin dengan baik.

Strategi yang dapat diterapkan pada masyarakat Samin adalah berpegang pada pokok metode dakwah yakni menggunakan metode dakwah bi al-hikmah, yakni berdakwah dengan menggunakan bahasa sehari-hari masyarakat Samin, masyarakat Samin, dan dengan menampilkan perbuatan nyata dan keteladanan (uswah) sehingga masyarakat Samin tidak merasa ada paksaan, konflik maupun rasa tertekan. Metode al-hikmah yang demikian dapat disebut sebagai alhikmah bi lisan al-haal, yang mencirikan dakwah kultural, yang sangat relevan dapat dalam menghadapi problem yang dihadapi masyarakat Samin mulai dari problem aqidah, pendidikan, hukum, kebudayaan, hingga problem akhlak. (uswah) sesuai dengan keadaan serta situasi dan kondisi masyarakat Samin.

\section{DAFTAR PUSTAKA}

Amin, Samsul Munir. 2009. Ilmu Dakwah. Jakarta: Amzah.

Aziz, Ali Moh. 2009. Ilmu Dakwah. Jakarta: Prenada Media Group.

Buhhanudin, Nandang. 2011. Mushaf AlBurhan Edisi Wanita. Bandung: CV. Media Fitrah Rabbani.

Hasan, Muhammad Tholhah. 2005. Islam Dalam Perspektif Sosio Cultural. Jakarta: Lantabora Press.

H. Hilman Hadikusuma SH. 1983. Antropologi Agama. PT Citra Aditya Bakti: Bandar Lampung.

Kardi, Hardjo. 1996. Riwayat Perjuangan Ki Samin Surosentiko. Bojonegoro: Tanpa Penerbit.

Machendrawaty, Nanik \& Agus Ahmad Safei. 2001. Pengembangan Masyarakat Islam: dari Ideology Strategi Sampai Tradisi. Bandung: Remaja Posdakarya

Munir, M., \& Wahyu Ilahi. 2006. Menejemen Dakwah. Jakarta: Kencana Prenada 
Media Group.

Munir. M., 2009. Metode Dakwah. Jakarta:

Kencana Prenada Media Group.

Primay, Awaludin. 2005. Paradigma

Dakwah Humanis: Strategi Dan

Metode Dakwah Prof. KH.

Saifuddin Zuhri. Semarang: Rasail.

Puteh, M. Jakfar. 2006. Dakwah di Era

Globalisasi: Strategi Menghadapi

Perubahan Sosial. Yogyakarta: Ak

Group.

Rosyid, Moh., 2008. Samin Kudus Bersahaja Di Tengah Asketisme

Local, Yogyakarta: Pustaka Pelajar. 2010. Kodifikasi Ajaran

Samin. Yogyakarta: Kepel Press. 2012. Perlawanan Samin.

Yogyakarta: Idea Press.

Saputra, Wahidin. 2011. Pengantar Ilmu

Dakwah. Jakarta: Rajagrafindo Persada.

Soekanto, Soerjono. 1999. Sosiologi Suatu

Pengantar. (Edisi Keempat 1990).

Jakarta: Rajagrafindo Persada.

Shaleh, Rosyad. 1977. Management Dakwah Islam. Jakarta: Bulan Bintang.

Syukir, Asmuni. 1983. Dasar-dasar

Strategi Dakwah Islam. Surabaya: ALIKHLAS. 